\author{
Dominika Łarionow \\ ๑ https://orcid.org/0000-0002-6920-6360 \\ Institute of Art History, University of Lodz \\ dominika.larionow@uni.lodz.pl
}

\title{
A PERFORMATIVE CONCEPT OF THE ARTIST - UNMATRICIZED ACTIONS EXEMPLIFIED BY THE WORKS OF ZOFIA LIPECKA
}

\begin{abstract}
The article is an attempt to apply the performative concept of the artist's theory formulated by Grzegorz Sztabiński to the analysis of the work of Zofia Lipecka. The artist works in France, but is of Polish origin. She creates works in various techniques: painting, video, installations, she touches on many topics: from the archeology of signs, the identity of the symmetry of nature, to ecology and historical memory. Lipecka's actions are unmatricized and cannot be easily defined. Thanks to this, they became an excellent material for analysis according to the assumptions of Sztabiński's theory. Its fundamental point is to give the artist freedom by using the participle phrase: "creating art".
\end{abstract}

Keywords: Performatics, aesthetics of the 20th century, Zofia Lipecka, the art of Polish emigration of the 20th century, art - ecology, art - memory, Grzegorz Sztabiński

At the turn of the millennium, performance studies ceased to be an aesthetic discipline or an intellectual, or methodological trend used for the analysis of selected works of art. They became a strong scientific paradigm, which was clearly formulated by the American theoretician Jon McKenzie ${ }^{1}$ who stated that we had entered the performance era. This inference stemmed from a seemingly quite prosaic assumption that in everyday life we either become the subject or object of some kind of performance. McKenzie works and writes

1 Compare: Jon Mc Kenzie, Performuj albo... Od dyscypliny do performansu, translated by Tomasz Kubikowski, Universitas, Kraków 2011. 
using English, which has determined the way of conducting analysis in this case. Performance studies were born in the USA and their emergence as a separate entity was closely connected with the linguistic value of the word itself, as the verb to perform has many meanings that go beyond the sphere of culture, towards human actions related to e.g. agility, but also efficiency e.g. regarding teamwork in a corporate system. ${ }^{2}$ This is how the concept of omnipresent performance in our everyday life originated - performance that appears at different stages of our human existence, not only in its intellectual aspect, but also in connection with our presence in the social, national, minority, professional, etc. sphere.

While acknowledging the performative shift in humanities research, the Polish aesthetician Grzegorz Sztabiński developed a "performative concept of the artist" that was theoretically to focus on the figure of the artist as a person, a human being entangled in the surrounding reality in its cultural, intellectual, historical, social, economical or, finally, mental aspect. At the outset of his inquiry, the researcher made a very important reservation, as he assumed that the "[p]erformative concept of the artist cannot be derived from considerations regarding the works of those who practice the so-called performing arts". ${ }^{3}$ This meant that the theory developed on the grounds of aesthetic research can be applied to any artist, but cannot be used as a methodological tool to conduct an analysis of works belonging to the trend in art which uses performance for creative actions that often have a spectacular character. Artefacts created in such a way are subject to other forms of evaluation, both in the realm of art criticism and aesthetics.

Sztabiński's concept redefined the attitude of the contemporary artist towards their work, as it was created in opposition to the dominating, especially in the 20th century, Marxist and psychoanalytic theories focusing on the entanglement of an individual in a system of social dependencies and mental determinants. In contrast, while conducting the analysis determining the contemporary role of the artist, the aesthetician assumed that present day humanities, e.g. through gender analyses, have questioned the identity of the creator understood from an essentialist perspective. "Paraphrasing [...] [Simone] de Beauvoir's words, we can say that one is not born, but rather becomes, an artist - and throughout their whole life". ${ }^{4}$ Sztabinski stipulates that the revolutionary feel of the thesis formulated in such a way is definitely much weaker than the words of the French feminist regarding the gender determination of

2 The topic was elaborated on by Tomasz Kubikowski, Amerykańska eksplozja, "Didaskalia" 2001 , no. 46.

3 Grzegorz Sztabiński, Performatywna koncepcja artysty w sztuce wspótczesnej [in:] Zwrot performatywny w estetyce, [ed.] L. Bieszczad, Libron, Kraków 2013, p. 31.

4 Ibidem, p. 36. 
a human being. However, his statements do bring a breakthrough, as the "performative concept of the artist" that he introduced undermines the fundamental conviction regarding the expressive character of the artist's actions and works. Inborn features neither determine the artist's identity, nor give them the status of a genius. Moreover, there is no identity that precedes and influences one's works, and determines their value. The postulate regarding honesty appears to be based on fiction when it comes to revealing the identity. This is because it is the artist's actions that comprise the identity that they are allegedly supposed to reveal. Thus, there are no real or fake, honest or distorted artistic acts. Their performative character consists in establishing the artist's identity that they are supposed to have originated from. Being an artist does not mean realizing certain primary possibilities that are granted in advance, but entails "unmatricized" and "undetermined" actions (...)". ${ }^{5}$

I believe that the works of Zofia Lipecka, a Polish-French artist, is a perfect example showing that the aesthetician's theories can have a real application in research on contemporary art. Lipecka was born in Łęczyca and she emigrated to Paris in the 1970s. In France, she completed her high school education and art history studies, gaining a $\mathrm{PhD}$ degree at the Art Contemporain department of Université de Paris I. In the years 1981-1984, she concurrently studied at École National Supérieure des Beaux Arts in Paris. She started working as an independent artist in mid 1980s. So far, she has exhibited her works in Paris, New York and Poland (Museum of Art in Łódź, Zachęta - National Art Gallery in Warsaw, Jewish Historical Institute in Warsaw), and her works are part of collections in Poland and abroad (Museum of Art in Łódź, Signum Foundation in Poznań, City of Rende in Italy, Fonds National d'Art Contemporain in Paris). Lipecka's works are unmatricized actions, as well as they have not been determined by any ideology or trend. Undoubtedly, they constitute a fully autonomous artistic concept.

In one of her texts/manifestos written in French, Lipecka mentioned the main tendencies in her own works. She stated there that in the mid 1980s her interests focused on history which she poetically called "l'épaisseur temporelle du réel", which can be translated as the "time thickness of reality". According to the artist's intention, this phrase should be used with reference to the first years of her work, but while analyzing the almost 40 years of her artistic activity, it is hard to resist the impression that the actions she has created have focused on history understood not only from the perspective of an ordinary dictionary meaning of the term. Among others, in her works, Lipecka often seems to semantically test human perception, exploring what else can be discovered when, like archaeologists, we subject the subsequent layers of soil to analysis, 
like new dimensions of reality. This is exemplified by the paintings (Indian garden and Untitled. Earth painting, 1988) created using a mixed technique, where Lipecka attached sand brought in the late 1980s from her journey to the USA to the canvases. When the fine grains had dried, she attempted, by scratching, scrubbing and drawing on the surface, to bring abstract forms out of them - ones that were to refer to the degraded and destroyed Native American culture. The foundation of her work was the inner conviction that the fine sand stores some hidden memory of the ancient tribe community destroyed by civilization and brutal colonization. The archaeology of meanings became the basis for further development of Lipecka's art. Undoubtedly, at the beginning she was guided by wonder and curiosity, and it was often connected with seeking mathematical correlation between the worlds, which she defined herself in the following way:

"The diversity of motifs that I use in my art inevitably leads to questions regarding their meaning. It seems to me that the sense is situated outside individual symbols - in the form itself. The repetition of certain shapes throughout the whole history of civilization, such as the spiral, checkerboard, or triangle, as well as their presence in nature, in amazing plant, animal or crystalline forms, and finally their structure: regular and symmetrical - seem to show cosmic harmony to me". ${ }^{6}$

That is why Lipecka was interested in the meanings of forms and viewed reality as if through them. Images with unobvious backgrounds are present throughout her whole artistic activity, very similar to the surfaces of old school blackboards where one can find some rectangles, triangles, spirals and circles under a layer of chalk. Alongside the development of art, these compositions started to evolve from geometrical forms to even tables of semantic rebus puzzles, which is documented in the film Zofia Lipecka à Vierzon (2020), where we first observe the creative process and then the artist explains the meanings of the rebus puzzles she has painted. The sense of the composition entitled L'histoire polonaise (Polish History) is especially memorable. Here some parts of the surface were wiped using a dirty sponge, creating paths on the greenish background of the "blackboard". The artist achieves this effect by preparing thick cardboard. Realistically painted shapes: leaves, a zebra and a fox emerge from the flat and seemingly monochromatic surface of the painting. They are accompanied by words and all the elements together make up a rebus puzzle. In the documentary, Lipecka explains the meaning of each element. The motto here is the derivative part of the Polish words where the stem liście (Eng.

6 After Andrzej Turowski, Nostalgie..., the catalogue of Zofia Lipecka's exhibition Natura odzwierciedlona/ Nature réfléchie, Muzeum Sztuki in Łódź, Łódź 1991, no page numbers. 
leaves) can be found. The artist simply recites: zgoni-liście (you rounded up), zebra-liście (you gathered), męczy-liście (you tortured), bi-liście (you beat up), zabi-liście (you killed), spali-liście (you burnt), patrzy-liście (you looked), milcze-liście (you remained silent), etc. The cacophony of words and murderous meanings explains the seemingly innocent drawings of leaves in combination with individual groups of letters. The whole work is deeply meaningful. The artist conducts narration in Polish, as that was the language used to create the composition, but later also fluently moves on to a French translation. The seemingly innocent rebus puzzle takes on a very accusatory meaning and it is not ordinary play derived from some childish games. In this case, language is the tool thanks to which the artist discovers new aspects of reality and the history of her country. It was similar with the American sand that reminded her of the Native American culture.

The unmatricized character of Lipecka's works can also be seen in her interest in ecology. In the 1990s, Andrzej Turowski assumed that the artist feels "manifold threats of the world and wants to manifest an ethical attitude, giving her art an ecological dimension". ${ }^{7} \mathrm{He}$ also explained his opinion in more detail in the following way:

"The reference to nature in Lipecka's works is two-dimensional: ethical and aesthetical. The first of the aspects is realized by the, so much needed today, ecological conscience, although in the artist's works it is mostly a form of defending (or questioning, perhaps?) the humanistic paradigm threatened by technology, a way of restoring (or perhaps questioning?) a human being's identity lost in the world of artificial discourses and simulated spaces. The aesthetical dimension is closely connected with the ethical one through the feel of nature - its "boundless symmetries" and amazing order - it places the notion of the sublime at the centre of contemporary reflection: the human, natural, artistic sublime". ${ }^{8}$

At that time, Lipecka was developing an archaeological way of imaging the world in her works. One of her tools was wax in which she sank realistic drawings of plants (Ziarna-fragment/ Graines-fragment, 1991 and Geometria roślin 32/Geometrie des plantes 32/, or she used the encaustic painting technique to draw plant shapes related to geometry, such as volutes/spirals or circles. Lipecka mainly focused on describing the shapes of nature, on extracting omnipresent symmetry rules from its forms. Back then, she was evidently guided by wonder, curiosity and the search for mathematical correlation between the

7 Ibidem, no page numbers.

8 Ibidem, no page numbers. 
worlds. The artist's position as an author in relation to the undertaken ecological topics was completely different than today, as the way she makes inferences now owes a lot to the analysis of ecological themes in contemporary art conducted by Paul Ardenne. ${ }^{9}$ This French art historian noticed that the 21 st century brought an important change, as nature with its wonderful qualities, magic, wilderness and mystery is no longer a passive object of art. Now it is art that wants dialogue with nature to co-create a discourse on equal terms. While analyzing the works of different artists, Ardenne came to the conclusion that they are able to construct art - to some degree - by imitating animals which often aggressively interfere with nature by their actions, as they dig holes, bite trees, build nests, make hollows, i.e. shape nature also understood as the surrounding landscape. The actions of an artist against the world of nature can be similar.

This way of thinking has now been undertaken a little à rebours (Eng. against nature) by Zofia Lipecka, as in her vision the artist can make a change through their work not as much in nature, but in the surrounding world, though understood mentally, not physically. It means that a painting, not as a frame or canvas, but as a representation, becomes a tool thanks to which we begin to see the surrounding reality in a different way. Lipecka wants us to start looking at ourselves not as the only ones, but one of many characters in the world of nature, functioning on equal terms with plants and animals. The artist has given up exploring the semantics of form. Her paintings from the Biotopie cycle (2014-2017) present nature seen through the stylistics of magical realism in which people and wild species of predators, such as tigers, lions and polar bears, can live in symbiosis without aggression. However, the artist has never had any illusions that such a reality could ever come true. This is evidently shown by the painting Biotopia 3 (2014) whose composition drowns in the wild greenness of a paradise jungle where dangerous predators are resting, while there is a fearless human couple in the river right beside them, as if not noticing the potential danger. It is an illusory vision of Paradise lost which is realistic in this representation in order to be imaginary at the same time. The world without aggression presented by Lipecka has been planned in detail. There is no aggression, as it has been suppressed thanks to a waterfall flowing in the background of this idyllic scene, whose whiteness is illuminated not by flashes of water foam, but pill capsules containing drugs that cure aggression and the bloodthirsty evil of the rules which govern the world of nature. In this vision, the magical medicaments are given to all the inhabitants of the garden, as if they were life-giving water, but at the same time they are discreetly hidden from the viewer and finding them becomes a turning point for properly recognizing

9 Paul Ardenne, Un art écologique. Création plasticienne et antropocéne, Éditions Le Bord de L'Eau, Bruxelles, 2018. 
the meaning of the whole work. It is similar in the case of two other paintings: Biotopia 4.Ocean (2015) and Biotopia 6 Ocean (2016), in which pills have been included in a vivid vision presenting the colourful life of a coral reef.

By hiding small elements, which are so important for her work, in her paintings, the artist plays a sophisticated game of riddles with the viewer, their sensitivity and mindfulness. This game is part of an artistic strategy that Lipecka has been using for years. I think that a brush, paint and canvas are a collection of indispensable items for the artist, thanks to which she performs a scientific diagnosis of the world, its problems, pains and memory, i.e. also its subconsciously hidden content. The Biotopie cycle is one of the elements of her multi-faceted artistic activity. Apart from the vision of the paradise garden, there was also an Arctic beach (Biotopia 10. Nord, 2017) with polar bears, seals, penguins and reindeers observing people bathing in the sea in wonder and astonishment. It seems that the couple does not notice floating chunks of ice. They are standing in the sea in their swimming suits, talking to each other as if they were beach visitors on summer holiday. The viewer is again confronted with a cognitive dissonance which will appear the moment the meaning of the composition is recognized. Its meaning is purposefully represented as a clash between human naivety and the consequences of climate warming coupled with the slow extermination of the inhabitants of Arctic areas.

Zofia Lipecka's paintings make an exceptionally strong impression on the viewer. These are perfect landscape paintings and their finesse results from precise brush movements and the evident sensitivity to colour and texture, intentionally clashed with the presented paradoxes of the present day. It seems that the artist wants to tell us that the civilization we surround ourselves with is only seemingly safe and elegant, and that it also seemingly constitutes only one of the worlds that are possible to live in. Next to us there is nature and the inner world that is hidden from the human being. The degradation, destruction and extinction that we cause as humans not only affect us, but also nature, which is dying while we keep on carelessly and naively bathing in the sea, instead of protecting it. Ardenne called this way of imaging "anti-Eden", as it shows destruction, disintegration and decay. Lipecka depicts both a dead forest (Biotopia 7 Dead forest, 2016) and poppies growing on rubbish (Biotopia 9 Coquelicots, 2016). This post-humanist and post-industrial destruction in her narration is absorbed by nature which even domesticates metal cans, synonymous with the dirt of civilization, with some innate vitality and will to regain the world despite everything.

In 2021, Lipecka gave up realistic paintings characterized by elaborate narration in order to return to painting on "school blackboards". Ecology, which had entered the story zone uncovered on the seemingly flat surface of the background, began to be related to searching for the hidden shapes of na- 
ture, such as stamens and pistils of flowers, or shapes of seeds and cells of organic organisms. The new fascination connects the artist's works with an art nouveau vision of the microscopic world. Her paintings, though, are not full of wonder regarding the richness of forms discovered in this way - they only relate to scientific biological diagnostics.

Zofia Lipecka's works cannot be classified as belonging to any clearly defined trends in modern art, as they escape any attempts to be historically analyzed, they are unmatricized. It also cannot be predicted what the artist will do, as she has a seeker's attitude, trying to solve any theme that she undertakes often using very different narrations. This is what she shocks and surprises the viewer with. I think that such a way of constructing the ethos of art and the artist in Lipecka's works has resulted from two events. The first one is connected with her migration during the period of puberty, connected not only with learning a new language, but also a different quality of life. It was especially important in the 1970s, i.e. when Poland belonged to the so-called Eastern Bloc remaining under the influence of the USSR and the communist economical-political system. Secondly, Lipecka is an artist who has gained in-depth knowledge of art history. She is interested in philosophy and other cultural discourses. This is probably why she treats art as a tool of sometimes even scientific diagnosis of reality.

The migration was connected with experiencing the rite of passage in all its forms. I suppose that the state of liminality, i.e. the moment of transition from being suspended between language, culture, space and personal relations, to identifying oneself with the new situation and country, is important for a creative personality. For the generation leaving Poland at the time of the Polish People's Republic, it was undoubtedly both a boundary and formative experience, as it was much more broadly connected with the feeling of otherness, experiencing the state of being a stranger and, most of all, isolation and a lack of any possibility to return to the home country, compared to the generations of Poles migrating for economic reasons after 1989. I suppose that migration made Zofia Lipecka feel the need to constantly surprise others, which was initially connected with the necessity of winning over some social group of natives, in order to anchor herself better as a human being, woman and personality in this different world, another country and new language. This habit might have given birth to a very interesting and positive personality feature which makes the artist constantly feel the need to surprise us with a new medium of expression, which causes continuous tension and the resulting great deal of work. When it comes to the experience of a foreign language that needs to be learnt as well as the mother tongue, for Lipecka it was enlightening in a one more important way, shaping her artistic ethos. It entailed the need to precisely explicate the sense of her own words, their meanders, nuances and metaphorical meanings. It is because before we become proficient foreign 
language users, we go through different stages of getting to know the different reality through words and their meanings. Throughout her whole artistic activity, Lipecka has been following the semantic aspect of culture. This has built her approach to history, sometimes entailing the understanding of art even as an autonomous archaeological tool (blackboards-rebus puzzles). At the same time, we get the impression that the artist has been tackling the same themes for forty years, but each time she searches for a different form, or sometimes even a different medium (videos) of expression. This resembles the need to accurately explicate one's own thoughts in a foreign language, but using known and well understood words. Her use of canvas, photography, or film becomes the substitute for the subject and verb, i.e. the elements of a sentence that are decisive for a language structure and shape the whole utterance. It is the artist who decides what medium will be most appropriate for the sense of the message that she wants to pass on to the viewer.

Sztabiński was undoubtedly right, as he pointed out that there is another aspect of the performative concept of the artist, connected with the artist's social role. The aesthetician referred to gender theories again. He wrote:

"From the point of view of the performative concept of the artist, the order of things that was previously regarded as given or existing, appears to be a construction dependent on the acceptance of the participants ("actors" and "viewers"). In connection with that, certain behaviours forced by the existing social discourse, i.e. a socially regulated and sanctioned formed of manufacturing the human being - as Butler puts it, referring to gender issues - can be accepted through certain performative acts, and then the right strategy for the situation of coercion is taken into account". 10

Here Sztabiński assumes that the artist, despite their different out-of-theeveryday position, is still affected by social pressure. That means questioning the paradigm regarding artistic freedom that was fought for and established by the avant-garde in the 20th century. I believe that, while creating the picture of the artist's dependence on society, the aesthetician definitely thought about a number of pressures that the artist succumbs to, starting with the most important one - economy, as it is directly related to the artist's everyday living situation. However, Sztabiński made an important reservation there, assuming that yet a different situation may occur. He wrote:

"It is also possible, however, to adopt a different strategy that is based on struggling for change, or to freely manipulate performative factors. This is sugge-

10 Grzegorz Sztabiński, Performatywna koncepcja artysty w sztuce wspótczesnej, 37 
sted by the idea of performativity which assumes that there is no natural or social "artistic" being that precedes acts. These acts, in turn, do not express an identity, but create it. As Butler emphasizes, it is not me who assumes and changes roles, but the assumed and changed roles make up what will be called $m e{ }^{.1}{ }^{11}$

Sztabiński's inference introduces, through Butler, a different paradigm related to understanding the artist functioning with relation to the époque that they live in. The language of the artistic expression that the artist uses within this concept is subjected to the strong determinism of the times, it becomes a "disguise". It is similar with the means that the artist uses, as they depend on the existing aesthetics, technological possibilities and even morality, as well as any other pressures that a human being is subjected to in society. In the case of Lipecka's works, it can be precisely pointed out that it was ecology that constituted the pervasive problem which became the topic of her art, tackled in different ways. Another important thematic range of key importance for the artist is memory - not only with reference to nature, but also the social-historical dimension of remembrance.

Lipecka's works are known to Polish critics especially because of the Holocaust remembrance themes that she has been incorporating in her creations since the 1990s and gradually developing by looking for new ways of expression to shape an autonomous narration of the memory of the crime (Warszawa-Matkinia, Projekt Treblinka, Po Jedwabnem). Lipecka's works representative for this field of interest have been exhibited in Poland twice: in 2008 at Zachęta - National Gallery of Art in Warsaw and in 2013 at Atlas of Art in Łódź. Her works devoted to the memory of the Holocaust are different from the "blackboards" and the ecological narration described above. It seems that Lipecka is constantly looking for adequate artistic language which serves to describe her own emotions that she wants to convey through her art. When the installation Po Jedwabnem was exhibited, the artist interestingly talked about her position as the author, including being morally coerced to take up the discourse on Jedwabne:

"Jedwabne is the name of a small town in north-eastern Poland where on July 10th 1941 Polish inhabitants brutally murdered their Jewish neighbours. After a whole day of a terrible pogrom, they burnt hundreds of men, women and children in a barn. For many years, the responsibility for the killings had been attributed to the Nazis [...] So far, I have not felt any special bond with Poland, the country I come from. Having spent most of my life in France, I have been rejecting any national or community feelings, identifying myself with culture without borders, until I read a book about the tragedy in Jedwabne.

11 Ibidem p. 37. 
I was totally annihilated and unable to stop myself from crying for many days. I felt especially and personally responsible. The book brutally uncovered the problem of my Polish identity, which, as it seemed to me, I had already dealt with. Against myself, I was discovering the negative side of my identity in the dark past of the country I was born in". 12

The installation Po Jedwabnem was not a painting, but became a mirror in which all the viewers looked at themselves. Lipecka gave up using brushes, but took a camera and text. Andrzej Seweryn read Szmul Wasersztajn's account of the killings in Jedwabne in 1941 - a document that was first to make the pogrom known to people. The actor was recorded by the artist without using the camera. He read the record of the witness's account in a balanced way, without exaggerated interpretation. For Lipecka, the literary-documentary description became a pretext to show the emanation of memory. The installation consisted of four walls, onto two of which projections were made - recordings of people's reactions to the text read by Seweryn, while the remaining two were covered with mirrors. The viewers of the installation were reflected in these large pieces of glass and, in this way, they also listened to Wasersztajn's testimony. The important thing for Lipecka was the reaction of a contemporary human being to the description of the crime whose nightmare seems to be something completely incomprehensible, as far as humanistic and moral values are concerned. Using a camera, the artist recorded the reactions of some people she had chosen. These were representatives of all age groups: young, middle-aged and elderly ones, also those remembering the war. Their reactions were filmed using the American shot against the background of white walls, sometimes including small elements of background space, e.g. old photographs. Though nameless, the recorded faces were partly recognizable, especially for a conscious viewer: Alina Margolis-Edelman, Marek Edelman, Aleksander Edelman, Andrzej Turowski. Zofia Lipecka was also one of the people. I believe, however, that the element which made the installation Po Jedwabnem cross the cognitive threshold to the greatest extent were not the projections of the human reactions to the tragic story, but the mirrors in which the viewers of Lipecka's works were reflected. Elżbieta Janicka identified the spatial situation in which the artist placed her viewers as an inherent part of an image which appropriates the viewer. The art critic wrote:

"A mirror chamber. A reflection chamber. Space for reflection - in the most literal sense of the word. In physics, the term reflection is related to returning something from a surface. In philosophy, it means the sense of self: cognition, the source of which is the cognizing subject, directed towards the

12 Zofia Lipecka, Po Jedwabnem, Zachęta - National Gallery of Art, Warsaw 2008, p. 47. 
cognizing subject. The mirror phase in psychology is the moment in individual development when the individual becomes itself - for itself, no longer only for the world. The moment of gaining their own sense of self and self-awareness is the moment when the looking-glass self is born.

The status of the viewer is instantly explained. The viewer is an element of the construction, but one and such that conditions it. [...] The viewer is the sine qua non condition of the undertaking. The installation does not work without the viewer, it remains incomplete. The viewer starts it and brings it into existence.

The viewer is an object here, confronting themselves with their subject condition. It is because Zofia Lipecka places the viewer in a situation of confrontation, mostly with themselves. In the context of Jedwabne, the artist sends us away and calls us to ourselves. The mirror structure is part of the work. It is something that the artist gives us in the experiment - something that she asks us to do. "Us", as there is more than one person here. Even when we are alone inside the installation". ${ }^{13}$

Mirrors also appeared in other Lipecka's works (Boites noires, 1995 and Microspaces, 1999), but only after the installation Po Jedwabnem did they become an important element of imaging that crossed the borders of illustrativeness; the construction of the active viewer co-participation was also established.

Later works of Lipecka created in relation to Holocaust themes have never attacked the viewer so explicitly. Since 2004, the artist has been painting pictures created on the basis of a photograph of a road leading to Treblinka. Every year, Lipecka travels from Paris to the small town which witnessed one of the most tragic crimes of the Holocaust. Like a stubborn documentalist, the artist takes a picture at the place where, in the 1940s, the Nazis took a photograph of the town sign with the word Treblinka in Polish and German. Later, based on the photographic image, a picture painted on canvas is created. Sometimes it is a realistic representation, but sometimes the world becomes deformed, as if the artist's eye, through the brush used, started to notice elements invisible for the camera lens. Eleonora Jedlińska wrote that "the paintings are both a unique form of giving testimony to our memory [...] and an attempt to face our inability to stop it, its fragmentary character, absence, as well as the need to force places, but also pictures to talk. Lipecka's paintings-photographs provoke us to ask questions about the meaning of protecting the past, remembering what is gone, the effort we constantly need to make to preserve the memory of the past, no matter how inconvenient and troublesome it may be". ${ }^{14}$

13 Elżbieta Janicka, Konfrontacja. O audiowizualnej instalacji Zofii Lipeckiej "Po Jedwabnem" (2001-2003), catalogue, Zofia Lipecka. Po Jedwabnem, [ed.] Hanna Wróblewska, Zachęta National Gallery of Art, Warsaw 2008, p. 29. 
The work Treblinka is an example of a work in progress, where the deciding organ is the artist's eye that sees things in another way, differently perceives reality out-of-the-everyday and transfers such a picture to the viewer. This project has been going on for many years and constitutes a continuous struggle of the artist with the criminal trauma that was experienced by Jewish people during WWII, and with space that appears in the work from a witness's position. The landscape performs a creative function in these paintings, as nature was present when the humans were killed. It is also present now, when the area is being appropriated and given a new identity connected with the everyday life of ordinary Treblinka dwellers.

Zofia Lipecka's works are neither homogenous, nor do they create a repeatable scheme or can be easily classified, as the artist uses different means and media, as well as boldly experiments with the meaning of image as an iconographic representation, spatial constructions, photography and video. And even though it seems that the topics she tackles were already defined a long time ago, as they have always been: history, memory, symbols, as well as ecology and nature as a fascination with form, the artefacts created have surprised us many times with a different approach to the themes. Lipecka finds her way, does not follow any trendy discourses and often literally anticipates them - like in the case of the ecological themes present in her works from the very beginning. The artist's works have never been determined by simple inference - they always make up structures that undergo multiplication, constituting an intellectual challenge for the viewer.

While formulating his performative concept of the artist, Grzegorz Sztabiński replaced the statement that "the artist creates art" with the expression "art creating" or "creating art". "With such a formulation, identity disappears as a place of creative activity determined in advance. The artist's "self" becomes a still indefinite way of determination that is open to the possibility of changes. Artistic activity will gradually fill in the possibilities". ${ }^{15}$ It can be concluded that Lipecka's creations are an emblematic example, becoming an unmatricized and undetermined work where the artist becomes a human being creating art. A critic following Lipecka's artistic activity does not know what they may be entangled in, as the topics that she subsequently undertakes also become new interpretation challenges. The American researcher McKenzie connected the notion of performativity with the term challenge, which he demonstrated by giving the omnipresence of performative challenges to the modern times. An analysis of the works of the Polish-French artist is connected with further

14 Eleonora Jedlińska, Kształty pamięci. Wybrane zagadnienia sztuki wspótczesnej, Wydawnictwo Uniwersytetu Łódzkiego, Łódź, 2018, p. 236.

15 Grzegorz Sztabiński, op. cit., p. 41. 
challenges and confrontations that the viewer is faced with. Summing up his reflections, Sztabiński wrote:

"This concept seems to suit the character of the contemporary artistic activity, freeing talking and writing about it from some of the existing difficulties. Whether or not the performative concept of the artist can also be applied to modern art, freeing it from personalistic burdens, still remains a problem to consider". ${ }^{16}$

It can now be concluded that the aesthetician's premonitions have been confirmed. The performative concept of the artist has contributed to analytical freedom, as one can perform an overall interpretation of the actions of the artists who now freely use different techniques and migrate between different languages used to artistically express their own thoughts and feelings. The multidisciplinarity of works has gained an equally multidisciplinary analytical concept which places the artist in the centre, acknowledging their out-of-theeveryday, free way of expressing their own "self". Zofia Lipecka is one of the

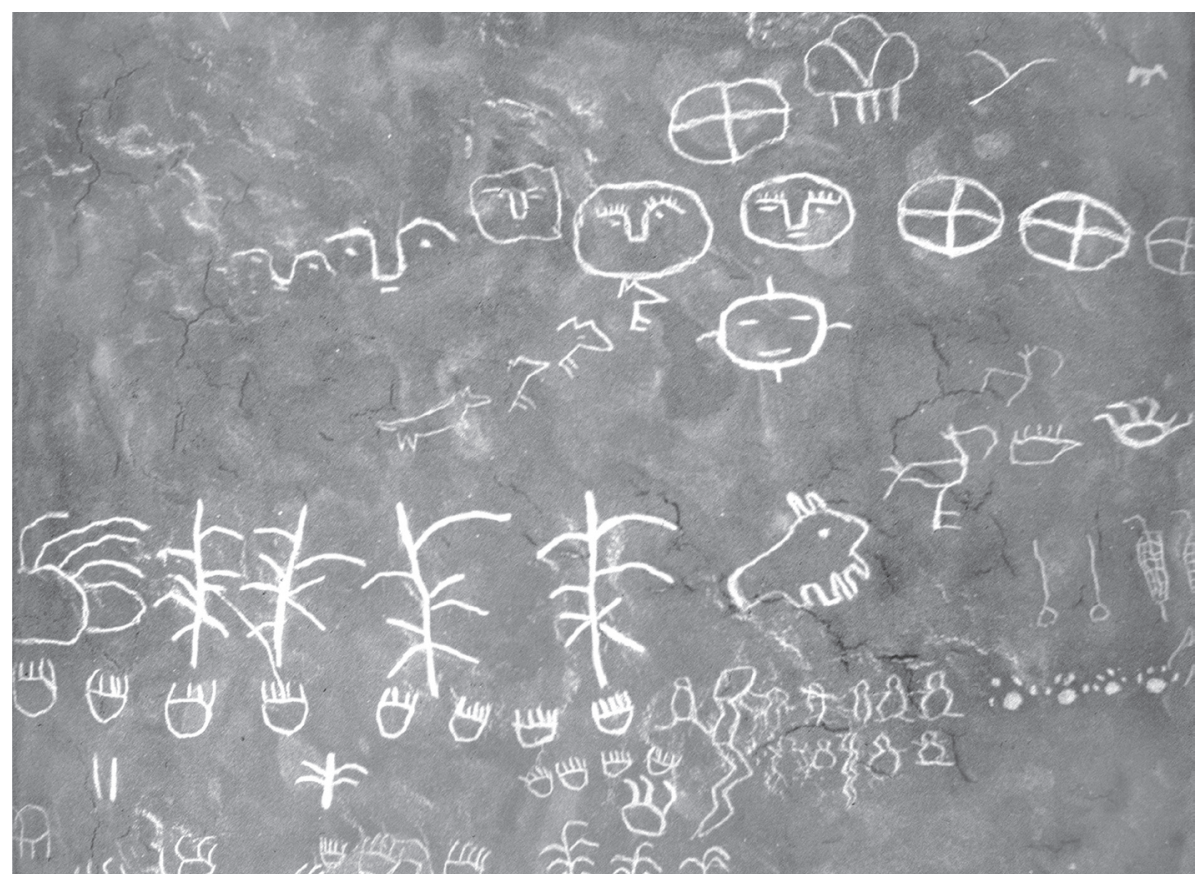

1. Zofia Lipecka, Indian garden, 1988; courtesy of the artist

16 Ibidem, p. 41. 


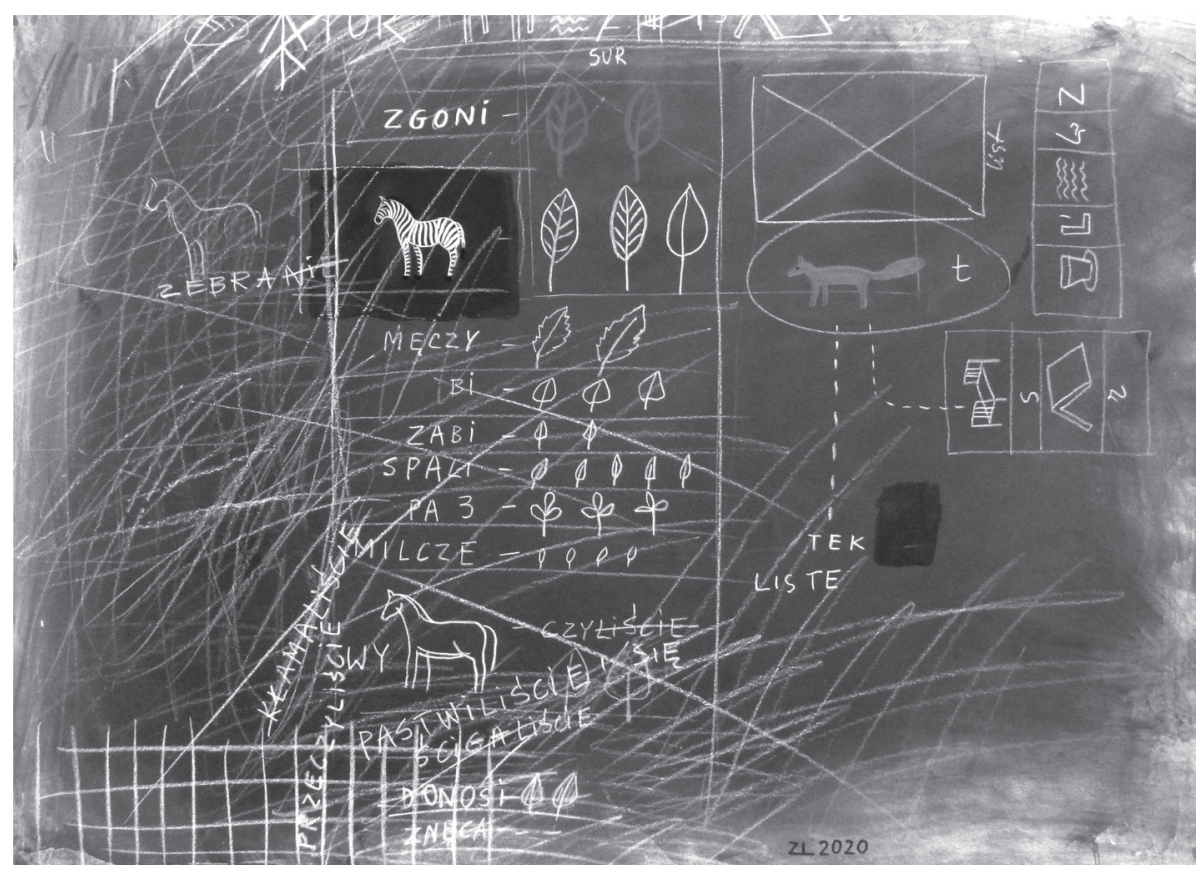

2. Zofia Lipecka, L'histoire polonaise, 2020; courtesy of the artist

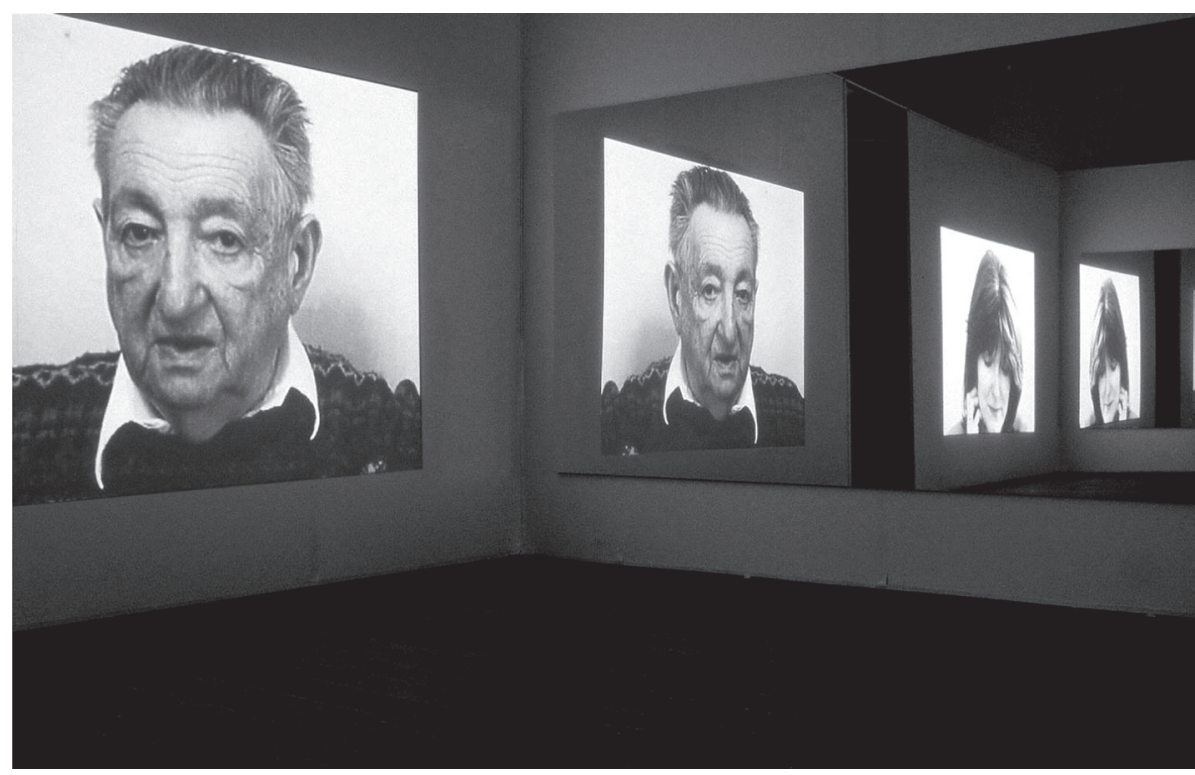

3. Zofia Lipecka, Après Jedwabne, 2003; courtesy of the artist 


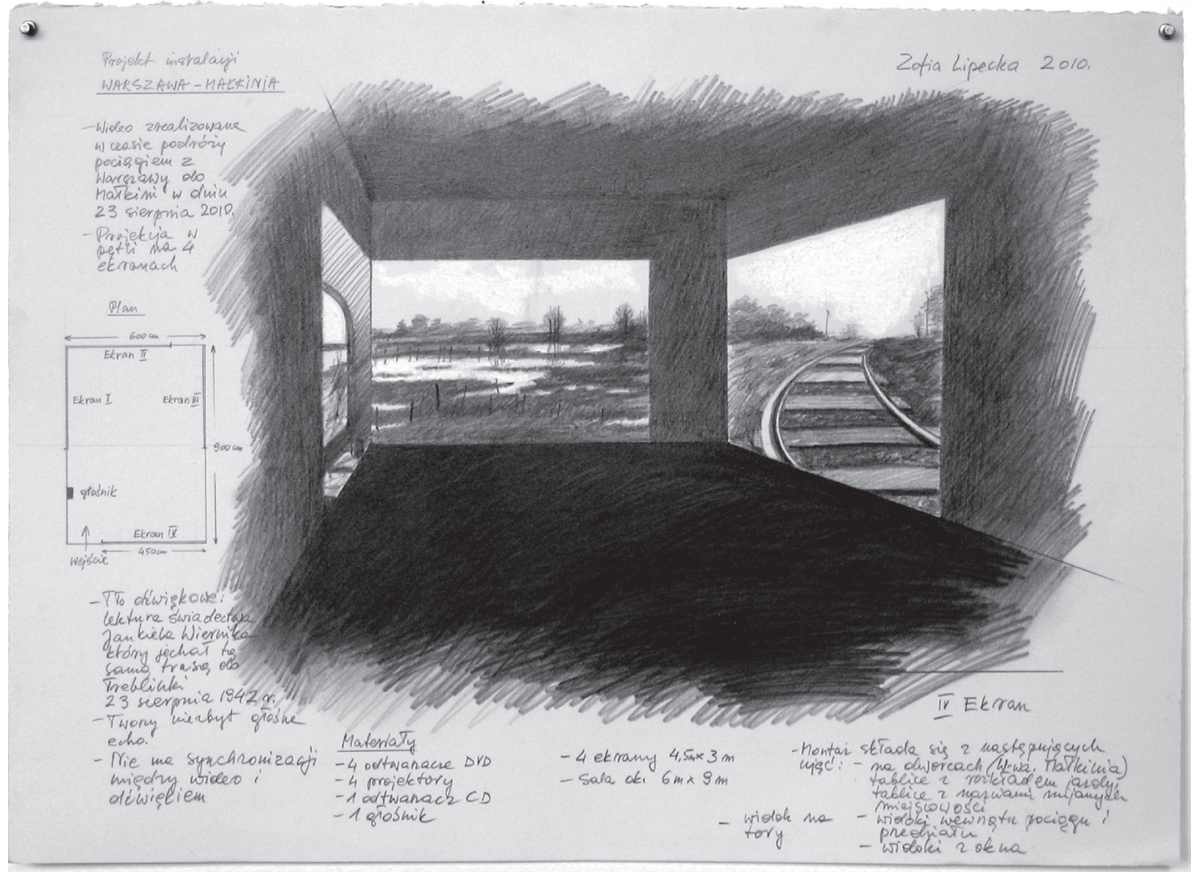

4. Zofia Lipecka, Warszawa-Malkinia project, 2010; courtesy of the artist

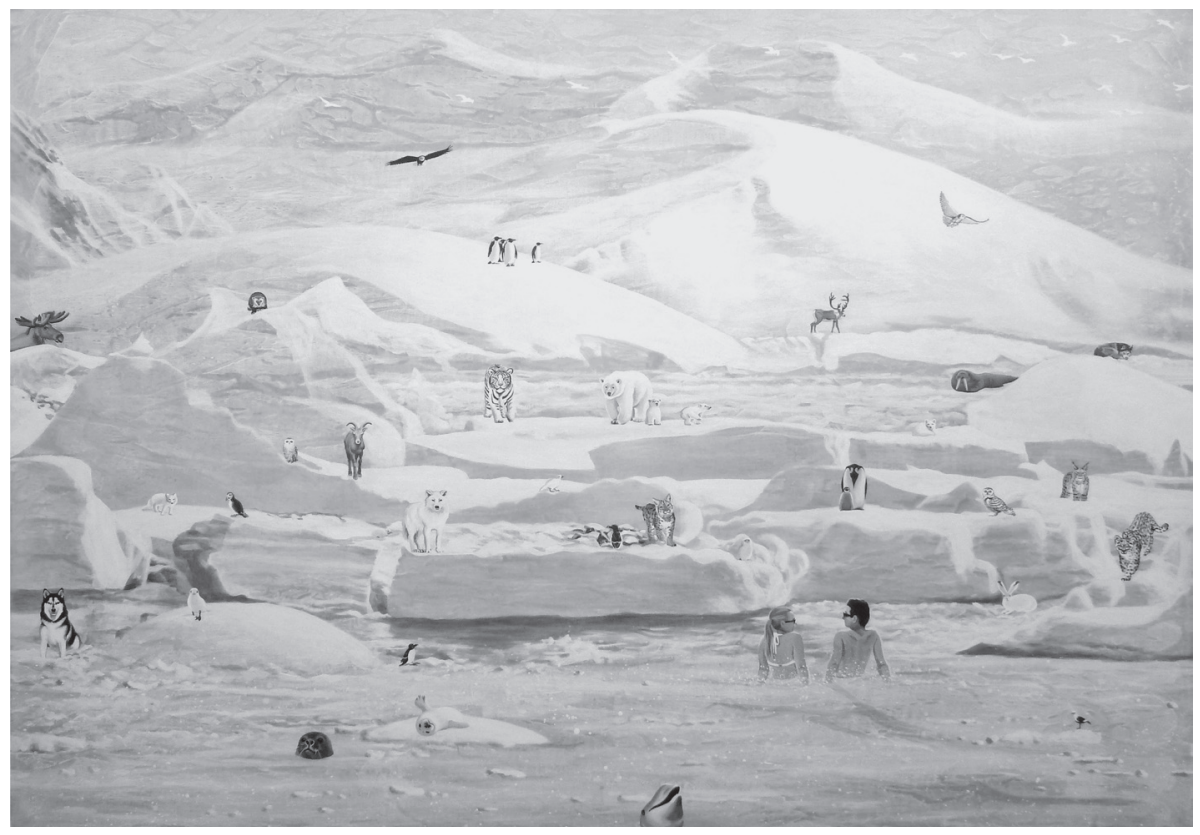

5. Zofia Lipecka, Biotopia_10 (Nord), 2017; courtesy of the artist 
post avant-garde artists whose works are anchored in different discourses and that is why her work perfectly fits Sztabiński’s concept.

\section{BIBLIOGRAPHY:}

Ardenne Paul (2018) Un art écologique. Création plasticienne et antropocéne, Bruxelles: Éditions Le Bord de L'Eau.

Janicka Elżbieta (2008) Konfrontacja. O audiowizualnej instalacji Zofii Lipeckiej "Po Jedwabnem" (2001-2003), catalogue, Zofia Lipecka. Po Jedwabnem, [ed.] Hanna Wróblewska, Warszawa: Zachęta - National Gallery of Art, pp. 25-40.

Jedlińska Eleonora (2018) Kształty pamięci. Wybrane zagadnienia sztuki wspótczesnej, Łódź: Wydawnictwo Uniwersytetu Łódzkiego.

Kubikowski Tomasz, Amerykańska eksplozja, "Didaskalia” 2001, no. 46.

Lipecka Zofia (2008) Po Jedwabnem, Warszawa: Zachęta - National Gallery of Art.

Mc Kenzie Jon (2011) Performuj albo... Od dyscypliny do performansu, translated by Tomasz Kubikowski, Kraków: Universitas.

Sztabiński Grzegorz (2013) Performatywna koncepcja artysty w sztuce wspótczesnej [in:] Zwrot performatywny w estetyce, [ed.] L. Bieszczad, Kraków: Libron, pp. 31-42

Turowski Andrzej (1991) Nostalgie..., the catalogue of Zofia Lipecka's exhibition Natura odzwierciedlona/ Nature réfléchie, Łódź: Muzeum Sztuki in Łódź.

\section{PERFORMATYWNA KONCEPCJA ARTYSTY - DZIAKANIA NIEZMATRYCOWANE NA PRZYKŁADZIE TWÓRCZOŚCI ZO- FII LIPECKIEJ (streszczenie)}

Artykuł jest próbą zastosowania teorii performatywnej koncepcji artysty sformułowanej przez Grzegorza Sztabińskiego do analizy twórczości Zofii Lipeckiej. Artystka pracuje we Francji, ale jest polskiego pochodzenia. Tworzy prace w różnych technikach: malarstwo, wideo, instalacje, porusza w nich wiele tematów: od archeologii znaków, tożsamość symetrii natury, po ekologię i pamięć historyczną. Działania Lipeckiej są niezmatrycowane i nie dają się łatwą zdefiniować. Dzięki temu stały się doskonałym materiałem do analizy według założeń teorii Sztabińskiego. Jej punktem zasadniczym jest danie artyście wolność poprzez użycie zwrotu imiesłowego: „, tworzący sztukę”.

Słowa kluczowe: performatyka, estetyka XX wieku, Zofia Lipecka, sztuka emigracji polskiej XX wieku, sztuka - ekologia, sztuka - pamięć, Grzegorz Sztabiński 
Dominika Łarionow - assistant professor at the Institute of Art History at the University of Lodz, in his research she deals with scenery and art of the 20th century. She is the author of several dozen articles devoted to 20th-century artists. She published the monographs: The Space of Images by Leszek Madzik, Lublin 2008, It is enough to just open the door... Objects in the work of Tadeusz Kantor, Łódź 2015. She is also the co-author of the three-volume monograph Changing Settings. History of Polish theater and social scenography of the 20th and 21st centuries, Warsaw 2020. The publication received the main prize of the Polish Society for Theater Research in 2021. 